\title{
WOMEN'S SUBVERSIVE INDIVIDUALISM IN BARCELONA DURING THE 1930S
}

SUMMARY: A focus on politically uncommitted working-class women alters the traditional historiographical emphasis on collective militancy in the Spanish Revolution. A large number of females acted ambivalently towards the cause, and revolutionaries were forced to confront women's individualism. In the search for the collective identities of class and gender, this individualism has been ignored. Instead of neglecting or condemning the personal, historians should try to understand how an exploration of the varieties of subversive individualism - resistance to workplace discipline, opportunism, and petty fraud - can expand the boundaries of social history and help to contribute to a theory of the state.

When Revolution erupted in Barcelona in July 1936, the revolutionaries needed all the help and support they could get from both the male and female workers they claimed to represent. On the radio and through other media, parties and unions made appeals for women's support in the struggle against rightwing Nationalists. We know that the most famous women of the period - the Communist, La Pasionaria, and the anarchosyndicalist, Federica Montseny - ardently and seemingly tirelessly worked for the victory of the Left. We are also well acquainted with the contributions of the militants of Mujeres Libres and other organizations. ${ }^{1}$ Yet the history of many other working-class women is less well known and nearly invisible. A focus on them alters the traditional emphasis on collective militancy in the Spanish Revolution. A large number acted ambivalently towards the cause, and revolutionaries were forced to confront the individualism of females who identified only marginally with the collective social project of the Left. Perhaps even more than their male counterparts, these women refused to sacrifice for the good of the struggle and defended personal needs, not those of the Republic or the Revolution.

The revolutionary society was unable to integrate large numbers of non-militant females who challenged its social disciplines. Because of the search for the collective identities of class and gender, working-class women's individualism has been ignored. Instead of neglecting or condemning the personal, historians should try to understand how an exploration of the varieties of subversive individualism - resistance to workplace discipline, opportunism, and petty fraud - can expand the boundaries of social history and help to contribute to the theory of the state.

${ }^{1}$ Mary Nash, Mujer y Movimiento obrero en España (Barcelona, 1981); Martha A. Ackelsberg, Free Women of Spain (Bloomington and Indianapolis 1991). 
Female individualism should not be identified exclusively with conservatism and reaction. Women's failure to sacrifice for the Revolution did not mean that they were pro-Franco or a feminine Fifth Column. In fact, authoritarian and fascist regimes were also forced to confront and control subversive individualism, but its persistence and growth during the Revolution in Barcelona suggests that a social project founded on collective property and worker participation had little attraction for many women. Subversive individualism shares much in common with what Alf Lüdtke has called Eigensinn. ${ }^{2}$ Both concepts explore aspects of everyday life, such as resistance to work, indiscipline, and pilfering. Yet ultimately individualism and Eigensinn are profoundly distinct. The latter does not encompass the conflict between the individual and society. Indeed, Lüdtke implies that Eigensinn might have been the basis for a more inclusive and liberated socialism. Subversive individualism, on the other hand, arises from the contradiction between the individual and society and thus recalls the neglected tradition of Stirnerian anarchism in which personal needs and desires took precedence over both capitalist and socialist wage labor. The persistence of individualism during the late 1930s in Barcelona demonstrates the inability of socialist society to overcome the split between the individual and the collectivity. Women's reluctance to sacrifice is an implicit critique of the anarchosyndicalist and Marxist revolutionary vision which many females felt too often renounced the personal for the social.

Ironically enough, female collective militancy may have been more common before than after the Revolution, in the period of turmoil immediately preceding and following the establishment of the Second Republic in April 1931. At that time and throughout the decade women defended their standard of living and sources of income. Although food riots seem rare, women did actively participate in a 1931 rent strike sponsored by the CNT (Confederación Nacional de Trabajo) against rapidly increasing housing costs. ${ }^{3}$ During the 1920s Barcelona's population had grown 62.43 percent, and this massive immigration had pushed rents to heights never before experienced. After the establishment of the Second Republic in April, the CNT demanded rent reductions of 40 percent. In June and July meetings of the rent strike committee attracted large numbers of women. Landlords, many of whom possessed only small properties, reacted with meetings of their own. However, the strike proved effective and aroused the participation of perhaps 100.000 in a city of over one million. Neighborhood solidarity made evictions difficult, if not impossible. In certain cases neighbors

${ }^{2}$ Alf Lüdtke, "Le domaine réservé: Affirmation de l'autonomie ouvrière et politique chez les ouvriers d'usine en Allemagne à la fin du XIX ${ }^{e}$ siècle", Le mouvement social, 126 (January-March 1984), pp. 29-52.

${ }^{3}$ The following information is from Nick Rider, "Anarquisme i lluita popular: La vaga de lloguers de 1931", L'Avenç, 89 (January 1986), pp. 6-17. 
threatened to lynch those who carried out the court's orders. Masses of women and children obstructed evictions of renters. The government reacted with repression. It imprisoned strike leaders, sent police to ensure removals, and generally acted in the interest of the landlords.

Women also participated in struggles over worktime. When a law prohibiting nightwork for women was altered, the change of schedule "was not welcomed by the workers" who then went on strike. ${ }^{4}$ Women wanted the prohibition on night work to apply to the hours between 11 P.M. and 5 A.M. "instead of 10 P.M. to 4 A.M." since they did not wish to rise one hour earlier. ${ }^{5}$ Women laboring at a textile factory in Badalona refused management's proposal that half of them work three days per week and the other half labor three other days. The women favored a workweek of the same three days for everyone. ${ }^{6}$ The Textile Union of the anarchosyndicalist CNT demanded that pregnant women receive four months maternity leave and that establishments with over 50 workers provide daycare centers. ${ }^{7}$

Women also fought collectively for higher pay. Textile entrepreneurs asserted that their workers had refused to contribute to the maternity fund, and when the industrialists attempted to deduct the women's share from their paychecks, "serious conflicts due to the resistance of the [women] workers" occurred. ${ }^{8}$ The Civil Governor had indicated that the law, which required approximately equal contributions from wage earners and employers, must be obeyed by both parties, but the women continued to strike to prevent deductions from their paychecks. According to the Governor, they refused to understand that maternity insurance would allow them to receive benefits which would greatly exceed their contribution. ${ }^{9}$ The Governor sent Civil Guards to the Catalan towns of Berga and Poblla de Lillet where "the union" promoted the agitation by circulating "seditious leaflets". ${ }^{10}$ Authorities feared that workers might react by stealing finished products or even machinery parts, and they ordered the Civil Guard to evacuate the factories to prevent a sit-down strike. Eventually, the women

4 Fomento del Trabajo nacional [hereafter known as Fomento], Memoria (Barcelona, 1929).

${ }^{5}$ Federación de Fabricantes, Memoria (Barcelona, 1930); women were not alone in fighting schedule changes. Laborers resisted a change of schedule which management tried to impose because of an electrical shortage due to drought.

6 Gobernador a Ministros, 10 August 1931, Leg. 7A, n. 1, Archivo Histórico Nacional [hereafter known as AHN].

${ }^{7}$ Francisco Madrid, Ocho Meses y un día en el gobierno civil de Barcelona: Confesiones y testimonios (Barcelona and Madrid, 1932), p. 194.

${ }^{8}$ Fomento, Memoria (Barcelona, 1932).

9 Gobernador Civil a Ministro Gobernación, 13 November 1931, Leg. 7A, n. 1, AHN; Albert Balcells, Trabajo industrial y organización obrera en la Cataluña contemporánea, 1900-1936 (Barcelona, 1974), p. 45.

${ }^{10}$ Gobernador Civil a Ministro Gobernación, 13 November 1931, Leg. 7A, n. 1, AHN. 
accepted their paycheck deductions which supplemented the law of 1907, which granted six weeks of maternity leave before and after birth. ${ }^{11}$

Women also defended their jobs and sources of income. To protest firings, they participated in one of the bloodiest strikes of the period. On 2 October, 760 workers walked out of a foreign-owned metalworking factory that employed 1100 workers in Badalona. ${ }^{12}$ Two days later, police arrested and jailed two workers for violating the right to work. The authorities then detained four women, whose militancy and solidarity with strikers provoked brutal treatment at the hands of the Civil Guard. ${ }^{13}$ Metallurgical workers protested the arrests and charged that police, who were engaging in loading and unloading, were acting as strikebreakers. On 24 October, the Unión Patronal de Badalona agreed to reinstate the dismissed workers but affirmed the employer's right to discharge personnel for "justified motives". Furthermore, the bosses prohibited union delegates from acting inside the factory but pledged not to dismiss workers who had a year of seniority. Workers were to return to work the following Monday, but, without notifying the authorities, they continued their "illegal" strike.

Tensions increased on 29 October, when strikers disobeyed a summons to disperse that had been given by mounted police armed with sabres. The Guard arrested four women, who were carrying stones, and five men. The next day, 250 "scabs", in the Governor's words, entered the factory. When a truck that was accompanied by policemen left the firm, strikers, "presumably from the Sindicato Unico [CNT]", attacked the vehicle with small arms. Those in the truck, perhaps Guards themselves, fired back and killed two strikers. The day after, the Governor responded to the workers' deaths by jailing the presidents of the transportation and constructon unions of Badalona. During the funeral of the strikers, the Civil Guard "was forced to charge [the crowd]".

Yet judgments concerning women's involvement in militant organizations must be mixed. Many women were less likely to join and lead unions than men because of their marginal commitment to the workplace. ${ }^{14}$ In 1930 , the $1,109,800$ Spanish working women constituted 12.6 percent of the total work force and 9.16 percent of their sex. Only 43,000 to 45,000 joined unions, and 34,880 to 36,380 of these belonged to Catholic trade-union movement. This relative aloofness from unions may be explained by the

${ }^{11}$ Balcells, Trabajo Industrial, p. 45; Rosa María Capel Martínez (ed.), Mujer y Sociedad en España, 1700-1975 (Madrid, 1982), p. 227.

${ }_{12}$ The following paragraphs are based on telegrams, October 1930, Leg. 40A, n. 2, AHN.

${ }^{13}$ In another, simultaneous metal workers' strike, Civil Guards injured several women by hitting them with their rifles. See Gobernador a Ministros, 18 October 1930, Leg. $40 \mathrm{~A}, \mathrm{n} .2, \mathrm{AHN}$.

${ }^{14}$ Statistics from Rosa María Capel Muñoz, La Mujer española en el mundo del trabajo, 1900-1930 (Madrid, 1980). 
female pattern of temporary employment. Some began to labor at 12 or 14 but quit immediately after they were married, which was usually between the ages of 25 and 30 . If widowed, they might return to the labor market. In 1922, Barcelona industrialists asserted that most women workers left their jobs to get married and that hardly any labored until retirement age. ${ }^{15}$ Yet in the 1930s - perhaps because of the Depression - mothers and daughters also engaged in wage labor. ${ }^{16}$ In $1930,65.6$ percent of working women were single, 19.29 were married, and 14.26 were widowed. In Barcelona, 65 percent of the active female population, which composed approximately 30 percent of wage earners, worked in industry.

Commitment to the family, whose budget wives controlled, may have dampened collective militancy. In certain families, which wished to acquire a small business or piece of land, women controlled the family budget. ${ }^{17}$ These women may have been reluctant to see themselves or their husbands join walkouts. Some female workers, who labored for a salary which complemented the earnings of other family members, were also recalcitrant regarding strike action. Women from the impoverished middle classes, who labored to keep up appearances, may have also resisted participation in militant movements. ${ }^{18}$ In July 1931, 560 workers - mainly office personnel and repairmen - struck against the telephone company, and young women seem to have been among the first to return to work..$^{19}$ During the conflict, three male strikers - who were probably members of a CNT affiliate - were stopped by police for trailing three non-striking señoritas. ${ }^{20}$ The strike ended in "failure", perhaps because of the lack of female support. Available figures show that men were much more likely to strike than their female counterparts, who often received half of male wages. ${ }^{21}$

During the Second Republic, especially during the bienio negro (19341935), union membership declined as the state and employers took repressive measures against workers' organizations. At the outbreak of Revolution, many wage earners - especially females most of whom belonged to no union before July 1936 - flocked into the CNT and, to a lesser extent, the

${ }^{15}$ Fomento, actas, 2 June 1922.

${ }^{16}$ Cristina Borderías Mondejar, "Evolución de la división sexual de trabajo en Barcelona, 1924-1980: Aproximación desde una empresa del sector servicios" (Ph.D., University of Barcelona, 1984), p. 458.

${ }^{17}$ Felipe Alaiz, "Hacia el Estajanovismo español", Tiempos Nuevos (October-November 1938); Rider, "Anarquisme", p. 12.

${ }_{18}^{18}$ Balcells, Trabajo Industrial, p. 81.

${ }^{19} 6$ July 1931, Leg. 7A, n. 1, AHN; 4,300 female workers were employed in the communications sectors - telephone, telegram, and post office - in 1930. See Capel, La Mujer española, p. 48; in 1933 almost 40 percent of telephone workers were women. See Borderías, Evolución, p. 166.

${ }^{20} 9$ and 15 July, 1931, Leg. 7A, n. 1, AHN.

${ }^{21}$ Capel, Mujer y Sociedad, p. 236; Mary Nash, Mujer, Familia, y Trabajo en España, 1875-1936 (Barcelona, 1983), p. 53. 
Marxist UGT (Unión General de Trabajadores). ${ }^{22}$ It should be underlined that many workers joined the unions not for ideological but for personal reasons: Life in revolutionary Barcelona was quite difficult without a union card. To eat a meal in a collective kitchen, to acquire welfare aid, to obtain or keep a job, to attend a technical training center, to get housing, to be admitted to a clinic or hospital, to travel outside of Barcelona, to be exempted from military service, etc., a union card was often desirable, if not necessary. ${ }^{23}$

According to the CNT's own figures, it represented only 30 percent of the Catalan industrial workers in May 1936, one month before the Revolution, down from 60 percent in $1931 .{ }^{24}$ Thus, "tens of thousands", many of whom were female, with little "class consciousness" or commitment to the goals of the Left entered either union in search of social protection and stable employment. ${ }^{25}$ A CNT manager of the power company thought that,

one of the principal errors of the unions was to force the workers to join one of them. We are not really sure about many of the huge number of new members, although it's not worthwhile to discuss this outside of the union. ${ }^{26}$

In June $1937 \mathrm{H}$. Rüdiger, a representative in Barcelona of the revived First International (AIT), wrote that before the Revolution the CNT had only 150,000 to 175,000 members in Catalonia. ${ }^{27}$ In the months following the outbreak of the war, Catalan CNT membership jumped nearly one million, of which,

four-fifths are, thus, new people. We cannot consider a large part of these people revolutionaries. You could take any union as an example of this. Many of these new members could be in the UGT.

This official of the resurrected AIT concluded that the CNT could not be an "organic democracy". In the rival union the situation was little different. One UGT official militant asserted that the Catalan Federation of the UGT had 30,000 members before 19 July and 350,000 to 400,000 afterwards. He recommended a new organization of the union since many affiliates lacked

${ }^{22}$ See Alberto Balcells, Crisis económica y agitación social en Cataluña de 1930 a 1936 (Barcelona, 1971), p. 198.

${ }^{23}$ Letters from militants in 933 and other carpetas, Archivo Histórico Nacional, Sección Guerra Civil, Salamanca [AS].

${ }^{24}$ Balcells, Crisis económica y agitación social, p. 198.

${ }^{25}$ Albert Pérez-Barò, 30 Meses de colectivismo en Cataluña 1936-39 (Barcelona, 1974), p. 47.

${ }_{26}$ Comité, 17 October 1938, 182, AS.

${ }^{27}$ Rüdiger, "Materiales", 8 May 1937, Rudolf Rocker Archives, International Institute of Social History [IISH]. 
energy and experience. ${ }^{28}$ Although union officials did not comment upon the gender of their new members, it is probably safe to assume that, especially in the textile sector, a disproportionate number were female. Some CNT unions discouraged the election of members who joined after 19 July 1936 to posts of responsibility in the organization or in collectives unless the new members were unanimously approved ${ }^{29}$ This rule must have had the effect of excluding most women from leadership positions. Therefore, the large influx of new members into the Catalan unions and political parties was not an indication of ideological conversion to anarchosyndicalism, socialism, or communism but an attempt by rank-and-file workers, especially women, to defend their own interests as best they could in a revolutionary situation. During the Revolution, the unions became integrated into the state. They therefore lost their status as independent organizations whose first priority was to defend workers' immediate interests and to protect dissatisfied wage earners. Instead they became responsible for producing efficiently.

At the beginning of the Revolution, the unions collectivized the large factories and encouraged workers' control in the smaller workshops. However, even after collectivization or worker control was instituted, many wage earners were reluctant to participate in collective activities at the workplace. They individually avoided attending factory council or union meetings or paying union dues. ${ }^{30}$ In fact, activists often claimed that the only way to get workers to attend assemblies was to hold them during working hours and therefore at the expense of production. ${ }^{31}$ In one large metallurgical concern, only 25 percent of the personnel participated actively in assemblies. ${ }^{32}$ The most active workers were over 30 , had at least five years seniority, and technical ability. ${ }^{33}$ We can assume that they were usually male. Frequently, assemblies merely ratified decisions taken by smaller groups of militants or technicians. Some workers - again probably including many women - felt uncomfortable and were reluctant to speak, let alone protest, during the meetings. For example, only 29 of 74 workers in a UGT-dominated clothing firm, a branch where women were the overwhelming majority, attended an assembly in October $1937 .{ }^{34}$ At other

28 Acta de la asamblea [n.d.], 469, AS.

${ }^{29}$ See debates in actas de asamblea, Cargadores, 24 July and 22 August 1937, 1404, AS.

${ }^{30}$ CNT Marítima, 7 August 1937; Boletín del Sindicato de la Industria de Edificación, Madera y Decoración, 10 October 1937; Sidero-Metalurgia, September 1937.

${ }^{31}$ Actas de Junta y los militantes de las industrias construcciones metálicas CNT, 25 February 1938, 921, AS.

${ }^{32}$ Anna Monjo and Carme Vega, Els Treballadors i la guerra civil (Barcelona, 1986), pp. 91-92; Monjo and Vega, "Les colectivitzacions industrials a Barcelona durant la guerra civil", L'Avenç, 70 (April 1984), p. 37.

33 Monjo and Vega, Els Treballadors, pp. 109-124.

34 See report, 1219, AS. 
meetings, even when the rank and file was present, it often arrived late and left early. ${ }^{35}$ UGT telephone personnel - who seemingly did not empathize with women's dual domestic and wage-labor burdens - criticized female colleagues, the majority of whom had joined the union after $19 \mathrm{July}$, as never having attended even one assembly. ${ }^{36}$ Some activists unsuccessfully proposed fines for members who did not appear at meetings. ${ }^{37}$

Even when unions improved working conditions, they had to confront the individualism of women workers. At the beginning of the Revolution, a number of textile collectives abolished piecework. Consequently when productivity of female wage earners dropped, male militants found themselves "haranguing the women workers". ${ }^{38}$ The CNT newspaper, Solidaridad Obrera, claimed that the women who were making uniforms in the new CNT tailoring shops were content, and it contrasted the space, lighting, and machinery of the Confederation's workshops with the unhygienic conditions that prevailed before the Revolution. ${ }^{39}$ The CNT daily proudly stated: "We are organizing some workshops with the same system as in the United States." Yet in June 1937 the Central Junta of Tailoring criticized the "immense majority" of workers for misunderstanding the Revolution." The rank and file had not yet realized that they must sacrifice and, as a result, plans for the collectivization of the tailoring industry had to be postponed. ${ }^{41}$

Several different incidents showed that non-militant females were reluctant to sacrifice for the Revolution and sometimes demanded pay for "volunteer" work. The UGT Sindicato de Vestir had called on four men and women to collect clothes for the troops. The volunteers did not "understand" that they would not be renumerated for their services and demanded their wages.$^{42}$ As in other social revolutions, the flight of the monied classes deprived considerable numbers of female domestics of their sources of income. These domestics were often more concerned with personal rather than collective needs. With the approval of the Catalan regional government, the Generalitat, bank accounts which had belonged to employers were frozen and used to pay household staff. The former servants, however, sometimes inflated the amount of their back wages..$^{43}$ Perhaps their

35 Asamblea, 29 November 1936 and 13 June 1937, 1404, AS; Monjo and Vega, Els Treballadors, pp. 83 and 123.

${ }^{36}$ Acta, 21 February 1937, 469, AS.

37 Acta, 21 February 1937, 469; Asamblea, 13 and 31 January 1937, 140.

38 Ronald Fraser, Blood of Spain (New York, 1986), p. 214.

${ }^{39}$ Solidaridad Obrera, 28 and 29 August 1937.

40 Boletín del Sindicato de la Industria Fabril y Textil de Badalona y su Radio, June 1937.

${ }^{41}$ Hoy, January 1938.

${ }^{42}$ Comité Ejecutivo de la Federación Local UGT, 27 November 1937, 501, AS. The Federation agreed to pay half the salaries.

${ }^{43}$ See files in Generalitat 240 , AS. 
bogus claims reflected the individualism of domestics and other workers who were in intimate contact with employers. Individualism, however, was not limited to former maids. Instead of striking over job security, as had occurred before the Revolution, workers were known to switch from one union to the other in order to find the organization which would be more sympathetic to their demands. For example, when two women CNT members were refused work by the Confederation's Metallurgical Union, they attempted to acquire UGT cards. ${ }^{44}$

Abandoning the pre-revolutionary practice of participating in rent strikes, a large number of families refused to pay their rent and gas/ electricity bills. Several weeks after the Revolution erupted, the Control Committee of gas and electricity considered employing the Antifascist Militias to collect debts from "elements who are taking advantage of the present circumstances to avoid paying their bills". ${ }^{45}$ Two months later, the committee complained to a representative of the CNT Construction Union that many consumers were dishonest,

always trying to find a way to swipe free kilowatts [. . .]. Unfortunately, working-class comrades are among the defaulters [morosos]. If we catch an upperclass defaulter, we give him what he deserves, but we cannot do anything to the workers since many plead that they don't have a job.

Militants wondered why despite the purchase of all available electric stoves, no increase in consumption had been recorded, implying that households, presumably with female consent, were tampering with their meters. At the end of the year the Committee studied a proposal to establish a special section dedicated to fighting fraud. ${ }^{46}$ Members suggested that the gas and electric meters no longer be read separately but together. Joint readings would not only save labor but also threaten potential defaulters with the interruption of both sources of power. The Committee wanted to take strong measures to force consumers who had moved to pay the bills which they acquired at their old address. ${ }^{47}$ One militant asked the Housing Commission not to rent to anyone who did not possess a receipt from a recent electric bill. ${ }^{48}$

As the fortunes of the Left dimmed throughout 1937, desire to sacrifice ebbed further, and many women textile workers seemed to have slackened their efforts. The unions responded by attempting to repress individual resistances to work. The CNT-UGT control committee of the firm Rabat,

4417 May 1938, 1084, AS.

45 19 September 1936,182 , AS.

4625 December 1936, 182 , AS.

7720 March 1937, 181, AS.

48 May 1937,181 , AS. 
where women were in the majority, warned that any comrade who missed work and who was not ill would lose his pay. The workers of this firm were told that disobedience could lead to fines and perhaps job loss in an industry where, it must be remembered, despite wartime mobilization of males, unemployment was high. All Rabat workers were required to attend assemblies under threat of fines. Only conversations concerning work were allowed during work hours. Other collectives in the clothing industry, which had unsuccessfully asked workers to increase production, also enforced rules forbidding conversations, lateness, and even receiving phone calls. ${ }^{49}$

Rather than organizing for higher wages, as had occurred in the early 1930s, individual females took unauthorized holidays during the Revolution. Those laboring in CNT offices ignored the slogan, "during war there are no holidays". Militants felt compelled to take disciplinary action against a female typist who refused to work Sunday. ${ }^{50}$ They feared that if the offender was not sanctioned, "many [women] comrades would miss Sunday work". A busy firm warned a female employee that if she continued to miss work to "party" (fer festa) she would be replaced ${ }^{51}$ In similar terms, the workers' committee of the Casa Alemany threatened two other women who took "unlimited leave". ${ }^{52}$ Even Mujeres Libres - the CNT's women's group which wanted to integrate women into the productive process - felt compelled to repress individualism. It accused one of its militants of unjustified absences, indiscipline, and immorality and took disciplinary measures against her. ${ }^{53}$

The repressive actions of unions and their satellite organizations at the workplace were paralleled at a wider level by the reconstruction of a powerful state. As early as March 1937, when the CNT was participating in government, all citizens between eighteen and forty-five (only soldiers, functionaries, and invalids were exempted) had to possess a "work certificate". The authorities could ask for this card "at any time" and would assign those who did not carry it to fortification work. ${ }^{54}$ If violators were found in "cafes, theaters and other places of amusement", they could be jailed for thirty days. In the columns of the CNT daily, Solidaridad Obrera,

${ }^{19}$ Reglament interior de la Casa Rabat, 10 January 1938, 1099, AS; Reunión, Rabat, 23 April 1938, 1099, AS; Assamblea ordinaria dels obrers de la casa "Artgust", 6 September 1938, 1099, AS.

so Comité Regional, Sección Defensa, 17 July 1938, 1049, AS. On the other hand, CNT and UGT clothing unions refused to authorize labor on Saturday afternoon. See 2 October 1937, 1219, AS.

51 Rabasso Palau, 25 October 1938, 1219, AS.

528 July 1938,1219 , AS.

${ }^{53}$ Letter from comité de la Fábrica No. 7, [n.d.] 1085, AS.

54 Décret instituant un "certificat du travail", 4 March 1937, 259, Archives diplomatiques [Paris]. For the certificates themselves, Generalitat 252, no. 13, AS. 
the socialist Luis de Araquistáin praised the Confederation for recognizing "the necessity of the state as a tool for the consolidation of revolutionary conquests. What a joy for a Socialist to read [. . .] the program of the CNT." 55 In March 1938 the CNT agreed with the UGT that the state should play the major role in directing military, economic, and social affairs. At the same time, the UGT and the CNT affirmed that a

salary which is tied to the cost of living and that takes into account professional categories and productivity must be established. In this sense the industries [controlled by the unions] will defend the principle of "the more and better the production, the greater the pay" without distinction to sex..$^{56}$

The failure of the unions to live up to this principle and the consequent persistence of salary and job discrimination may be partially responsible for female indiscipline and indifference. Women identified less with the workplace than men because of low pay and uninteresting work. The Revolution, while leveling wage differentials to a certain degree, destroyed neither the lower salaries of women nor much of the traditional sexual division of labor. When the Federación Local of the UGT needed a secretary or a cleaner, it naturally searched for women. ${ }^{57}$ In the Comedor Popular Durruti all the waiters, cooks, and dishwashers were male. The first two categories earned 92 pesetas and the third 69; whereas, the seven cleaning women earned $57.5{ }^{58}$ In the large factory of Espana Industrial, where over half the personnel was female, women earned 45 to 55 pesetas per week; whereas men received 52 to $68 .{ }^{59}$ In a big metallurgical collective, women in the same professional category as their male counterparts earned less pay. ${ }^{60}$ The proposed minimum salary for male telephone workers was 90 ; for women $70 .{ }^{61}$ When UGT telephone workers assembled to discuss military training, they agreed - with the assent of female participants - that women would receive instruction as nurses, not soldiers. ${ }^{62}$

The unions were sometimes insensitive to women's needs. When box makers encountered economic problems, CNT militants approved the motion not to pay female workers, "who had other means of support". ${ }^{63}$ In

${ }^{55}$ Quoted in José Peirats, La CNT en la revolución española, 3 vols (Paris, 1971), 3, p. 36.

${ }^{56}$ Document cited in ibid., 39.

${ }^{57}$ Comité, 22 May and 1 September 1937, 501, AS.

${ }_{58}$ March 1937, Generalitat 282, AS.

${ }^{59}$ H.E. Kaminski, Los de Barcelona, translated by Carmen Sanz Barberá (Barcelona, 1976), p. 181.

${ }^{60}$ Monjo and Vega, Els Treballadors, p. 87.

${ }_{61}$ Acta de la asamblea, [n.d.], 469, AS.

${ }^{62}$ Acta de la asamblea, 21 February 1937, 469, AS.

${ }^{63}$ Reunión, 22 December 1936, 1204, AS. 
other cases, some firms continued to provide separate dining facilities for the sexes, effectively institutionalizing prewar customs which, for example, tended to define certain social spaces as off limits to women. ${ }^{64}$ In another instance, the unions felt compelled to rationalize the backward Catalan textile industry in order to increase efficiency. Rationalization meant that the mostly female labor force had to work in the factory and abandon the home, where they had performed outwork or, as it was called, trabajo a domicilio. Women therefore came to have less control over their work schedule, and mothers were forced to make new arrangements for childcare. ${ }^{65}$

The increasingly harsh economic situation in Barcelona made women less likely to have the time or inclination to sacrifice or even work for the Revolution. Women continued to bear the double burden of wage and domestic labor without, of course, the help of modern household appliances. These burdens increased as the economic situation in the city rapidly deteriorated. Wartime inflation certainly aggravated discontent, as wholesale prices increased more than two and one-half times during the Revolution. ${ }^{66}$ At the end of 1936 and at the beginning of 1937, women demonstrated against the shortage of bread. The various political parties, especially the Communist, attempted to use the discontent caused by inflation to increase their popularity. Indeed, the famous May Days of 1937, when male Communists fought against anarchosyndicalists and anti-Stalinist leftists, may have been caused, in part, by female unhappiness over rising prices and increasing shortages. At any rate, on 6 May 1937 female demonstrators showed their rebelliousness by taking direct action. Continuing the Barcelona tradition of popular seizure of food supplies, "a large group of women descended on the port of Barcelona where they looted a number of vans filled with oranges". ${ }^{67}$ Basic foodstuffs were rationed, and housewives were forced to wait in long lines. By 1938 milk, coffee, sugar, and tobacco were in very short supply. No deaths from hunger were reported in 1936 and only

${ }^{64}$ Kaminski, Barcelona, p. 63; see also Annik Mahaim, Alix Holt, and Jacqueline Heinen, Femmes et mouvement ouvrier: Allemagne d'avant 1914, Révolution russe, Révolution espagnole (Paris, 1979), p. 185.

65 Martha Ackelsberg, "Revolution and Community", in Susan Bourque and Donna Robinson Divine (eds), Women Living Change (Philadelphia, 1985), p. 104.

66 Josep Maria Bricall, Política econòmica de la Generalitat (1936-39), 2 vols (Barcelona, 1978), 1, pp. 101-118. In an unconventional - but simplistic - economic analysis, UGT railway men asserted that the wage-price spiral was caused by the excessive salary demands of workers and criticized their "indiscipline" while calling for the "restoration of authority". See Informe, 5 September 1937, 467.

${ }^{67}$ Solidaridad Obrera, 7 May 1937; Juzgado General de Contrabando, 1336, AS. On women's demonstrations, see Enric Ucelay Da Cal, La Catalunya populista: Imatge, cultura, i politica en l'etapa republicana (1931-1939) (Barcelona, 1982), pp. 309-323.

${ }_{68}$ Estadística: Resumenes demográficos de la Ciudad de Barcelona. El período 1936 a 1938 y de 1939, p. 22. 
9 in 1937, but in 1938 the figure rose to $286 .{ }^{68}$ Hunger continued to incite other women's demonstrations over foodstuffs ${ }^{69}$ Little wonder that helping themselves and their families survive left women with little time for meetings of the collectives or other public affairs.

Even in such difficult circumstances, revolutionaries made a sincere attempt to meet certain female demands. They attempted to socialize female domestic labor by organizing daycare centers, which, predictably enough, employed only women workers. Even so, the relatives of female workers (usually mothers or mothers-in-law) probably continued to bear primary responsibility for childcare ${ }^{70}$ Militants sometimes cared for children of compañeras so that they could attend union meetings. ${ }^{71}$ Activists legalized abortion and made contraception more freely available. They simplified marriage procedures and enabled party and union officials to certify de facto marriages or what libertarians preferred to call "free unions". The Revolution fostered the improvement of retirement, health, and maternity benefits.

When compared to the pre-war situation, revolutionaries reduced wage inequalities and offered more job opportunities. In November 1937, again with the assistance of the government, Catalan organizations participated in the establishment of an Instituto para la Adaptación Profesional de la Mujer which allowed women to master not only secretarial and culinary skills but also engineering, electricity, and chemistry. ${ }^{72}$ The CNT-supported Mujeres Libres campaigned to reduce the higher illiteracy rate among women and attempted to create a technical school which would provide training to women to enable them to replace mobilized males. ${ }^{73}$ Militants of this organization offered to "scour factories and workshops stimulating workers to produce the maximum" and encouraging them to volunteer for the front and fortification work. ${ }^{74}$

The desire to integrate women into the productive process was also the goal of the campaign against prostitution. While condemning males who frequented prostitutes, anarchosyndicalist activists and Mujeres Libres' members argued for the reform of the members of the oldest profession through the therapy of work. ${ }^{75}$ They wanted to copy the Soviet model

69 Fraser, Blood, p. 452.

Torderías, Evolución, p. 471.

${ }^{71}$ Martha A. Ackelsberg, "'Separate and Equal'? Mujeres Libres and Anarchist Strategy for Women's Emancipation”, Feminist Studies, 11 (Spring 1985), 1, p. 74.

2 Ramón Safón, La educación en la España revolucionaria, translated by María Luisa Delgado and Félix Ortega (Madrid, 1978), p. 55.

${ }^{7}$ Mujeres Libres, 17 February 1938,529 , AS. On the integration of rural women into the urban workforce, see Ackelsberg, Free Women, p. 119.

74 A todos los sindicatos, 25 April 1938, 1084, AS.

${ }^{75}$ Dr. Félix Martí Ibáñez, Obra: Diez meses de labor en sanidad y asistencia social (Barcelona, 1937), p. 77. 
which, it was thought, had eliminated streetwalking. Federica Montseny, the CNT Minister, asserted that the Revolution offered prostitutes the chance "to change their lives and become part of the society of workers". ${ }^{76}$ This was indeed ironic since there is some evidence that before the Revolution certain women opted to become prostitutes precisely to avoid productive labor and poor working conditions. ${ }^{77}$ The anti-prostitution campaign reflected a certain puritanism among militants. Although, as mentioned, abortion was legalized and birth control information made available, some activists recommended that sex and childbirth be delayed until after the Revolution, "when tools inton': the symphony of work". ${ }^{78}$ Yet sex and prostitution undoubtedly persisted, especially since female domestics who had lost their jobs because of the flight of the monied classes joined the ranks of the pleasure professionals.

The UGT campaign to adapt women to the workplace was more successful than the anti-prostitution efforts. The Marxist union wished to cooperate with the CNT to train female apprentices to fulfill the needs of the war. ${ }^{79}$ According to the Secretary-General of the Barcelona UGT Federation, "Catalan women had always demonstrated a love of work and great ability in the workplace". ${ }^{80} \mathrm{He}$ demanded that certain collectives end their practice of paying women less than men even if they performed equal work ${ }^{81} \mathrm{He}$ also urged the unions to promote women to leadership positions in their organizations. In some workshops women began agitating for equal salaries. ${ }^{82}$ In others, mothers received a twelve-week paid maternity leave and thirty minutes daily for nursing. ${ }^{83}$

In August 1938 a female UGT official asked member unions about the possibilities of hiring more women. ${ }^{84}$ The responses of union leaders revealed both the state of Catalan industries and a range of male attitudes towards working females. The Secretary-General of the Woodworkers' Union replied that the lack of raw materials and electric power prevented the integration of women into his branch. He also asserted that women did not possess the skills to substitute for woodworkers in this still unstandard-

${ }^{76}$ Quoted in Kaminski, Barcelona, p. 67.

$n$ Dorsey Boatwright and Enric Ucelay Da Cal, "La Dona del Barrio Chino", L'Avens,, 76 (November 1984), p. 29.

${ }_{78}$ On legalization of abortion, see Mary Nash, "L'Avortament legal a Catalunya", L'Avenf, 58 (March 1983), pp. 188-194. On prostitution and sex, see Ackelsberg, Free Women, pp. 135-140.

79 Consejo de la Federación Local UGT, 2 and 5 October 1937, 501, AS.

Informe al Ple, 7 August 1937, 1322, AS.

${ }^{81}$ The idea of equal pay for equal work received support from the UGT Graphics Union. See Informe, [n.d.] 1049, AS.

${ }_{22}$ Asamblea, R. Pujol Guell, 11 November 1937, 1085, AS.

${ }^{83}$ Reglamento Interior, Eudaldo Perramon, 1 September 1938, 1219; Secciones Modistas UGT-CNT, 2 July 1937, 1336, AS.

${ }^{84}$ UGT, letter from Elissa Uris and militants' responses, August-September, 1049, AS. 
ized sector. In addition, this sexist UGT leader believed that "with honorable exceptions" women were qualified only for "simple" tasks, such as varnishing, not for heavy or dangerous work. The UGT Health Workers' Union claimed that the CNT job monopoly prevented it from hiring more women who were "biologically" better suited for health-care positions.

In other sectors, war needs introduced changes in the traditional division of labor. In rural post offices, women occupied the places of mobilized or deceased male relatives, and in the cities they began to labor as mail carriers. Despite the memory of female strike breakers in the early 1930s, UGT Postal Union officials recommended that women also serve in offices. The Secretary-General of the UGT Paper Union believed that with proper training women would be able to perform most jobs in paper production but not in carton manufacture which demanded more brute strength. The Paper Union was proud of its record of female employment both in the factories and within the union itself. The Graphics Union cited an example where two women printers produced as well as their male counterparts. In the textile industry, 80 percent of the 250,000 workers were female, but only the lack of raw materials and loss of markets prevented the employment of even more women.

Thus despite sincere efforts to integrate women into a collective social project, female individualism persisted and perhaps increased when compared to the pre-revolutionary situation. In other words, female consciousness was as likely to produce individual actions to defend what the historian Temma Kaplan has termed the goal of "preserving life" as it was to foster a collective defense of the nurturing role.$^{85}$ Female individualism reflected alienation from organizations which claimed to represent the working class. This indifference to parties and unions demonstrated the immediate priority which many women gave to the personal. Working for a distant socialist or libertarian society was a secondary goal. Furthermore, women had less reason to sacrifice. Males continued to dominate the revolutionary organizations, and while opportunities for women expanded during the Revolution, it was clear that men would continue to rule even if the Left emerged victorious. Male militants and soldiers were sure to suffer if the Republic lost, but women, on the other hand, might find it easier to avoid identification as "reds" and thus imprisonment or death. ${ }^{86}$

This is not to argue that working-class women were crypto-franquistas

${ }^{85}$ See Temma Kaplan, "Female Consciousness and Collective Action: The Case of Barcelona, 1910-18”, Signs, 7 (Spring 1982) pp. 548-565.

${ }^{86}$ Perhaps for similar reasons of prudence, many females were cautious about obtaining legal abortions and preferred to practice traditional methods of abortion and birth control. See Mary Nash, "Marginalisation and Social Change: Legal Abortion in Catalonia during the Civil War", Paper delivered at XVII Annual Conference of the Spanish and Portuguese Historical Society, University of Minnesota (April 1986). 
but rather that they would offer resistance to any regime - Left or Right which impinged upon their own personal interests in the workplace, in the streets, or at home. Social historians have neglected individualism for several reasons. By its very nature social history involves the study of groups, not individuals. Although its focus has shifted away from parties and unions to grass-roots movements and gender, it continues to examine aggregates. In addition, individualism has almost always been associated with free-market capitalism, if not reaction. Individualism, though, may have a critical and even a subversive side. The refusal to work and to sacrifice negated the social revolutionary vision of Marxists and anarchosyndicalists. Many women did not find satisfaction at the collectivized workplace, and they refused to dedicate themselves to a revolution whose aim was to make them better wage laborers. To combat their resistance to workplace discipline, opportunism, and petty fraud, anarchosyndicalists instituted a repressive order in the collectives and collaborated with Socialists and Communists to construct a powerful state capable of controlling the varieties of subversive individualism. The inheritors of both the anarchist and Marxist traditions failed to overcome the division between female individuals and society. 